\title{
ISM CODE ON VESSELS WITH OR WITHOUT IMPACT ON A NUMBER OF INCIDENTS THREATS
}

\author{
Jerzy Herdzik \\ Gdynia Maritime University, Marine Power Plant Department \\ Morska Street 81-87, 81-225 Gdynia, Poland \\ tel.: +4858 5586430, fax: +48585586399 \\ e-mail: j.herdzik@wm.umg.edu.pl
}

\begin{abstract}
It was presented short analysis of connection ISM Code on vessels on the number of incidents threats. Introduced into force ISM Code in 1998 and 2002 (contained in chapter 9 of SOLAS Convention) as obligatory on vessels have had the aim of decreasing the number of injuries, serious injuries, fatalities, other incidents threats and total loses during vessel operation in maritime shipping. The next aim vicariously was improving the maritime safety and prevention of marine pollution from ships. As a result of ship-owner and crew requirements, it should eliminate from shipping market the bad and poor management systems of charterers or ship operators and improper qualified crewmembers. The company and the ship shall comply with the requirements of ISM Code and the company shall have the Document of Compliance (referred to in regulation 4 of ISM Code).

After about twenty years when ISM Code was in force some comparisons, conclusions and remarks were presented. It is observed the decreasing number of vessel total losses but other comparisons is not so clear due to different definitions of incident being obligatory in states of flag and different databases in the different Memoranda of Understanding. The influence of introducing ISM Code on maritime shipping is serious in good or bad matters (e.g. the increasing of bureaucracy).
\end{abstract}

Keywords: shipping, vessel, incident threats, fatalities, ISM Code

\section{Introduction}

It may be noticed that the number of total losses of the vessels has been decreasing during last twenty years from about 200 vessels to 85 in 2015 (see Fig. 2.) [8]. How it is possible if the world fleet and seaborne trade are growing every year about 3-5\% (Fig. 1).

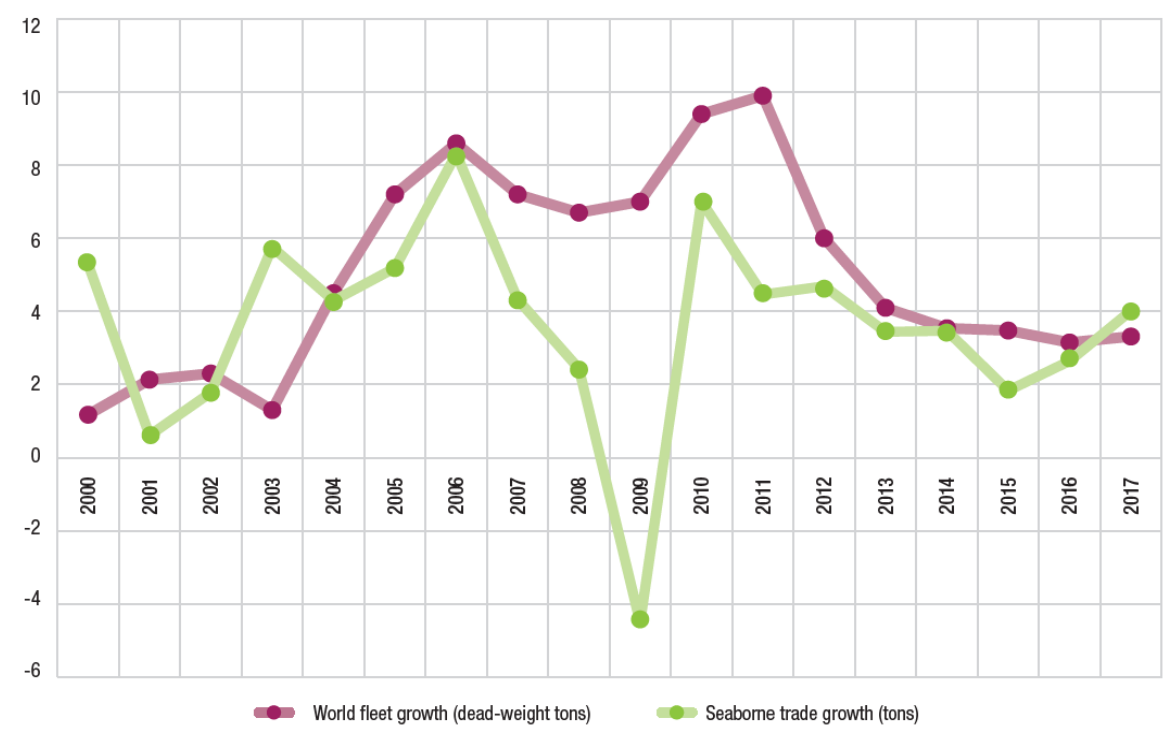

Fig. 1. Annual growth of world fleet and seaborne trade in 200-2017 [6] 
The International Management Code for the Safe Operation of Ships and for Pollution Prevention (ISM Code) was adopted by the International Maritime Organization by resolution A.741(18) [5]. Introduced into force ISM Code in 1998 and 2002 (contained in chapter 9 of SOLAS Convention) as obligatory on vessels have had the aim of decreasing the number of injuries, serious injuries, fatalities, other incidents threats and total loses during vessel operation in maritime shipping. The next aim was vicariously improving the maritime safety and prevention of marine pollution from ships. As a result of ship-owner and crew requirements, it should eliminate from shipping market the bad and poor management systems of charterers or ship operators and improper qualified crewmembers leading to crew negligence and inadequate vessel maintenance and as a consequence increasing the risk of failure or more serious incidents.

The company and the ship shall comply with the requirements of ISM Code and the company shall have the Document of Compliance (referred to in regulation 4 of ISM Code). This document shall be issued by the Administration, by an organization recognized by the Administration, or at the request of the Administration by another Contracting Government [5]. For ship-owner, this is crucial for the possibility of obtainment the permission on vessel operation.

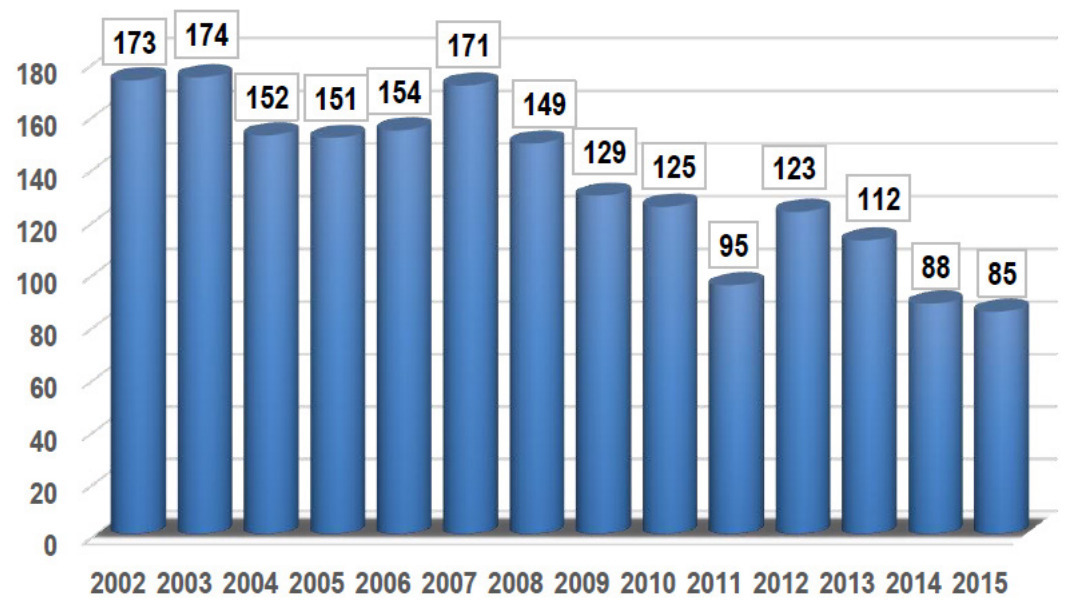

Fig. 2. Total losses of vessels in years 2002-2015 (over 100 gross tons) [8]

As the consequence of ISM Code introduction the reporting of marine incidents (to special database) are obligatory. The world was divided into nine Memoranda of Understanding on Port State Control (MoU). The majority of European countries (with Russia Federation) and Canada belong to Paris Memorandum of Understanding. The United States co-operate with a few Memoranda but do not belong to anyone. Looking for the number of reports (Fig. 3) it may be seen a big disparity between seas around the Europe and the rest of world. Is it possible that European waters are so dangerous for sea transport?
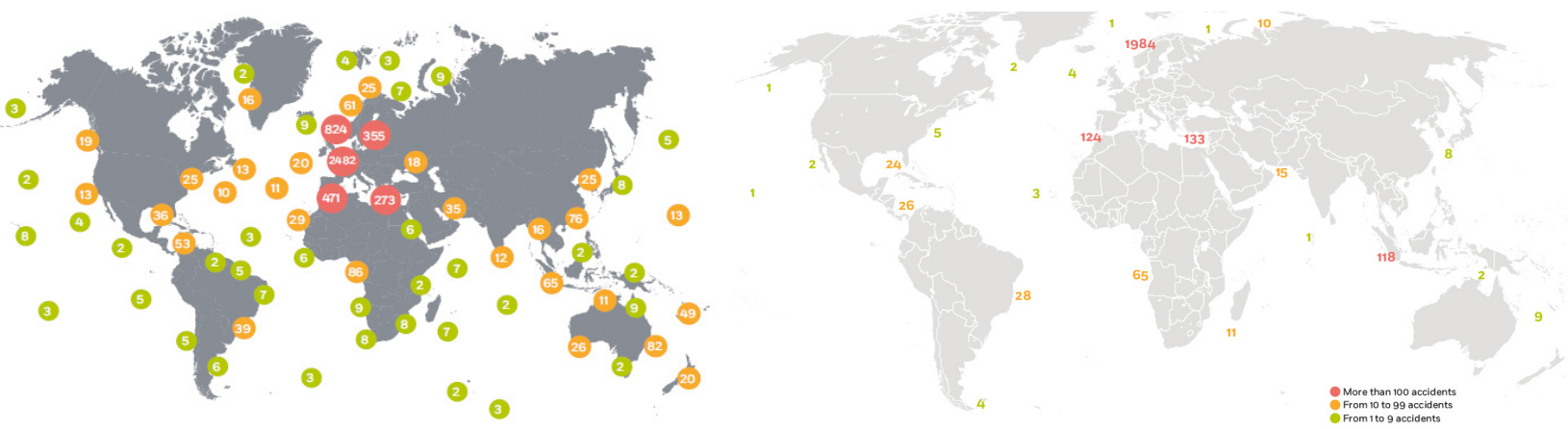

Fig. 3. The number of marine incidents in worldwide reported in years 2011-2013 (left side) and global distribution of marine casualties and incidents from 2011-2017 (right side) [3] 


\section{Twenty years of ISM Code being in force}

\subsection{The changes during twenty years in vessel operation manners}

Due to technical development, the vessel operation manners are still change. It was introduced Preventive Maintenance System (PMS). Schedule of planned maintenance actions aimed at the prevention of breakdowns and failures. Such system was prepared by engine manufacturers as a proposition as a recommendation for the fulfilment of requirements classification societies. It is seemed that the better manner of engine operation is Predictive Maintenance (PdM), which the using of techniques that help determines the condition of in-service equipment in order to predict when maintenance should be provided. It allows for minimizing the costs of scheduled repairs but needs information about the technical state of an engine through the diagnostic system when the engine is in service. Examples of PdM are as follows: vibration analysis, infrared thermography, oil analysis, visual inspections. It is a big challenge because information should be proper showing the moment for corrective maintenance. PdM program reduced costs about $8-12 \%$ in comparison to PM system [15]. The next benefits are reduction in downtime, increase the engine readiness to work, elimination of breakdowns up to $70 \%$ and of course reliability. There are still many difficulties for implementation PdM system.

It is still in research the better manners of maintenance systems, which give the fulfilment of the most requirements.

\subsection{The effects of acting ISM Code}

There are many effects after introducing into force ISM Code, like $[1,4,10,11,13]$ :

- the safety of a vessel and crew is the priority for ship operator,

- ship-owners should create their own regulatory regime and should show that they are complying with it during certification process and future vessel operation,

- the Safety Management System (SMS) should help the vessel crew to discover bad routines and weaknesses and give a chance to correct them before an incident happens,

- all dangerous actions taking on-board have prepared special procedures,

- increasing the seaworthiness taking away from possible dangerous situations,

- helps to evaluate the risk (for insurance market),

- if a non-conformity is found after an accident, it must be reported, investigated and analysed. Afterwards the root cause of the accident can be determined and an effective corrective action applied to ensure that such occurrence is avoided on that vessel,

- squeezing human errors out of ship operations (decreasing the coefficient of human error as a main cause of incidents),

- the crew negligence is now treated as management failure and needs quick corrective actions,

- ISM Code seems to be like a double-edged sword. It is a main source of information for insurers, cargo interests, and damaged third parties. On the other hand it is a great help for ship-owner showing him what he should do in complying the code,

- probably many others.

\subsection{Additional aspects of acting ISM Code}

The necessary for reporting all incidents gives the possibility for creation of databases. Examples are given in Tab. 1.

On the base of information access, some analysis and statistics were prepared. Taking into comparison the number of incidents in Canadian waters (presented in Fig. 4) and the number of vessels involved in incidents in European waters (presented in Fig. 5) the different conclusions could be done. 
Tab. 1. Information sources and databases about marine incidents [2]

\begin{tabular}{|l|l|l|}
\hline Source/ database & Country & Administration/ database administrator \\
\hline ORION & Great Britain & HSE \\
\hline $\begin{array}{l}\text { HCR - Hydrocarbon Release } \\
\text { Database }\end{array}$ & Great Britain & HSE \\
\hline Collision database & Great Britain & HSE \\
\hline $\begin{array}{l}\text { MAIB - Marine Accident } \\
\text { Investigation Branch }\end{array}$ & Great Britain & $\begin{array}{l}\text { Dept. Environment, Transport and the } \\
\text { Regions }\end{array}$ \\
\hline PTIL & Norway & PSA - Petroleum Safety Authority \\
\hline BLOWOUT & Norway & SINTEF \\
\hline DEA/EASY & Denmark & DEA - Danish Energy Agency \\
\hline $\begin{array}{l}\text { WCID - Well Control Incident } \\
\text { Database }\end{array}$ & International & $\begin{array}{l}\text { OGP - International association of Oil } \\
\text { and Gas Producers }\end{array}$ \\
\hline Common Reporting Format Project & International & $\begin{array}{l}\text { NSOAF - North Sea Offshore Authorities } \\
\text { Forum }\end{array}$ \\
\hline Performance Measurement Project & International & IRF - International Regulators' Forum \\
\hline $\begin{array}{l}\text { WOAD - World Offshore Accident } \\
\text { Database }\end{array}$ & Norway & DNV (classification society) - access paid \\
\hline
\end{tabular}

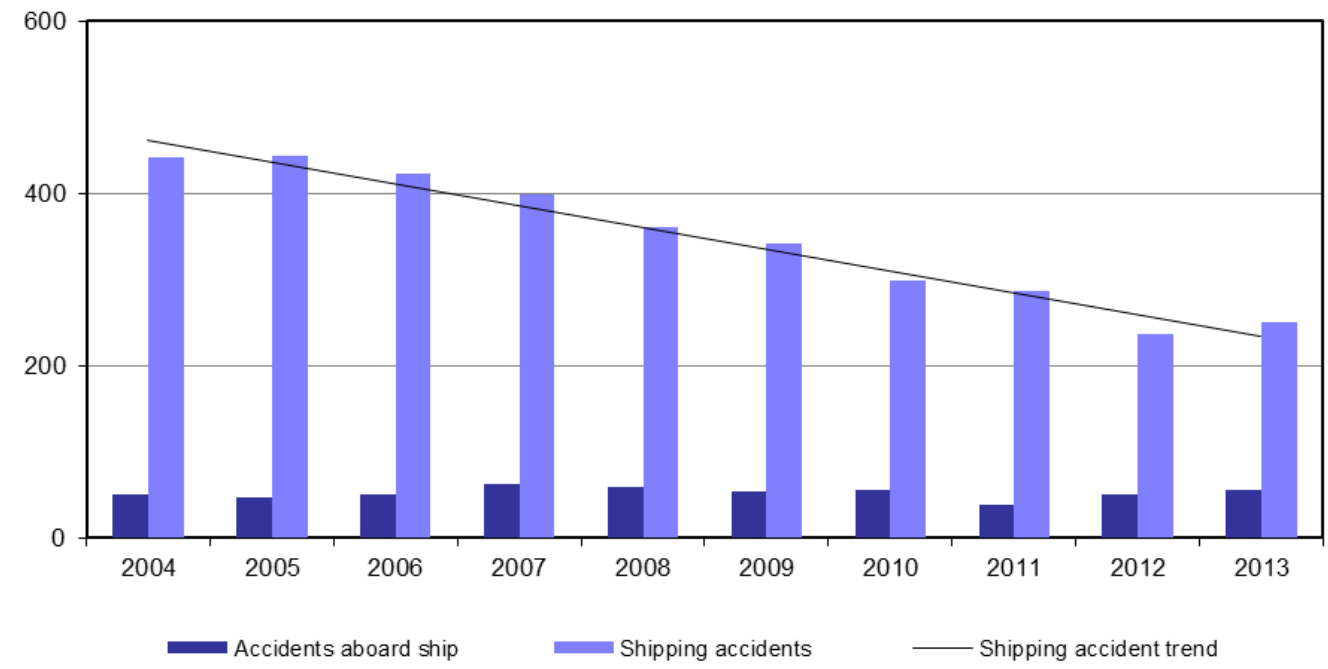

Fig. 4. The number of incidents in Canadian waters in 2004-2013 [12]

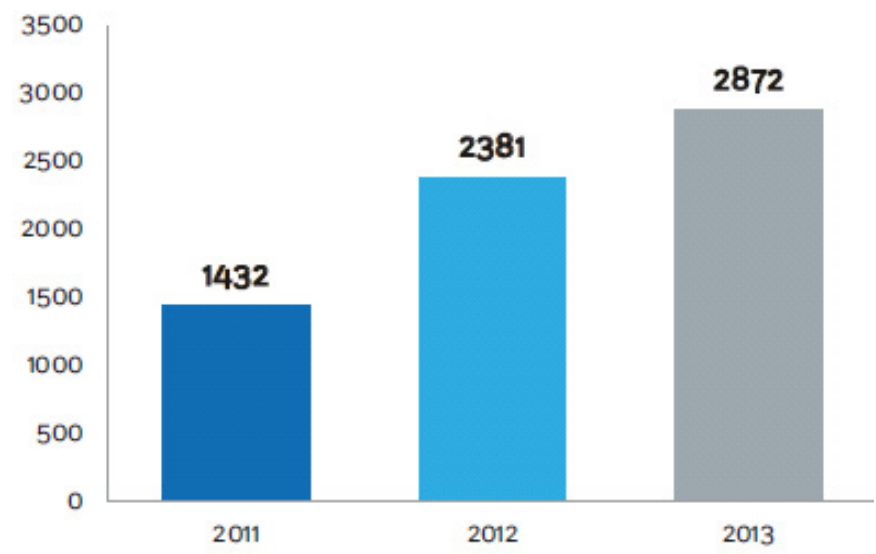

Fig. 5. Number of vessels involved in incidents in 2011-2013 in European waters [3]

Looking again at Fig. 3 it may be seen different trends. The European waters seem to be the most dangerous. The traffic level, area of traffic, sea hydro meteorological conditions, type of 
vessel has an influence on incidents number of course. Looking at the marine traffic presented in Fig. 5, it may be seen the number of vessels and their routes. Of course, European waters are crowd. Total intra-EU trade makes about $36 \%$ of world sea trade. The risk of incidents is proportional to the vessel traffic volume. It should be highlighted there are more factors having the influence on the risk like the trade area, weather and hydro meteorological conditions, traffic regulations, etc. [10].

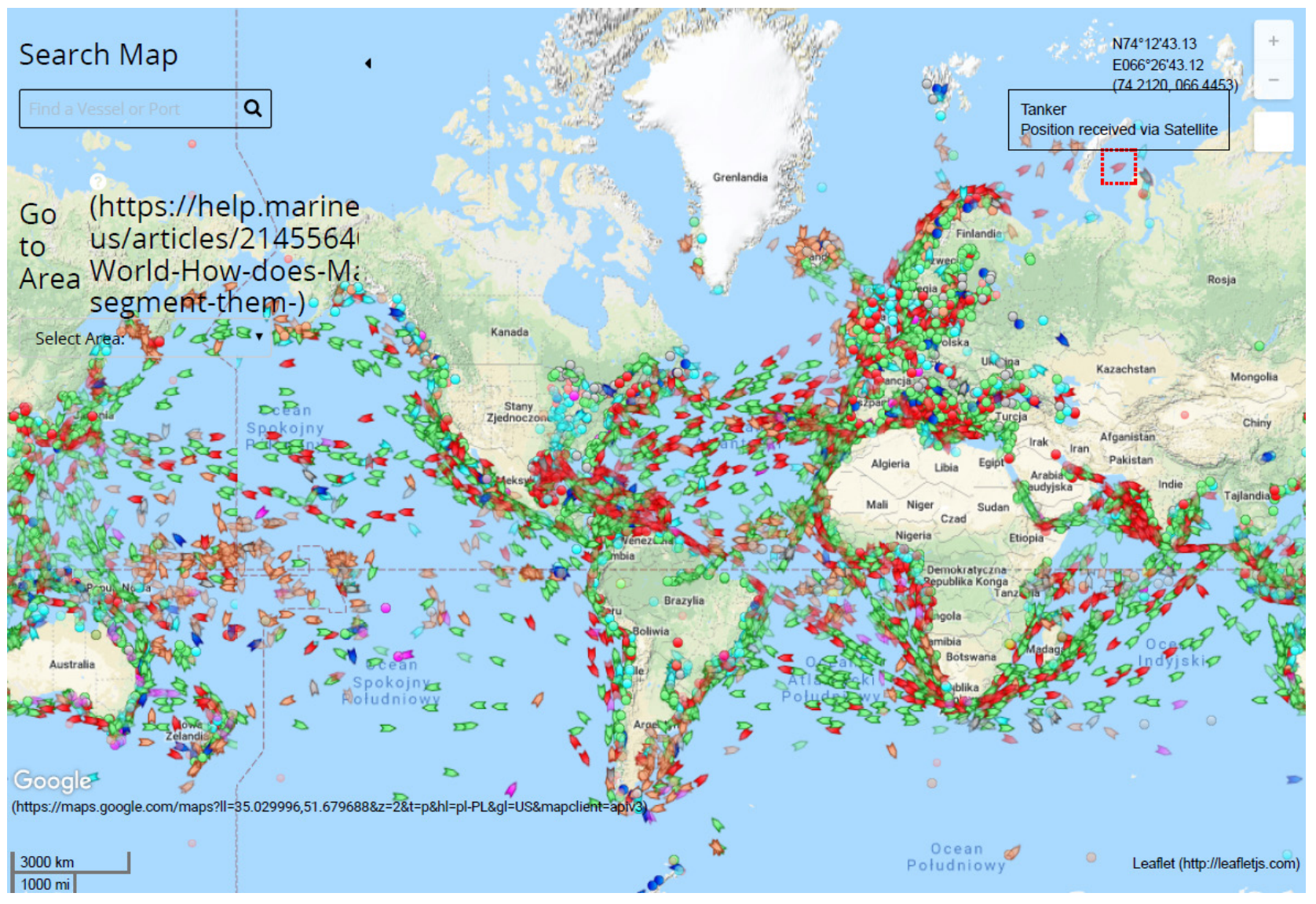

Fig. 6. Worldwide marine traffic on page marinetraffic.com [14]

In reality, the most important factor is the manner and requirements of incident reporting. It should be calculated only the total losses, fatalities and serious injuries. In such case the European waters seems not to be "special area". The tendency of decreasing the number of incidents is observed worldwide.

\section{Collecting, elaborating and publishing information about marine casualties and incidents}

\subsection{Incident limitation during vessel operation}

The transport by sea is the most important for worldwide market. The importance of transport safety rises. Management procedures should ensure the safest possible operation of vessels and maximum attainable prevention of marine pollution. There was prepared procedures for monitoring that "what should be done is being done". As new technologies are incorporated into on-board operations, vessels become more complex to operate. Due to increasing of vessel sizes and complexity of on-board operations the risk of serious incidents also rise [7,9]. The way of reducing required human intervention can also leads to a decrease in incidents. Approximately $75 \%$ in number of incident reasons are human factor. In 2011-2016, it was almost 15 thousand marine liability insurance claims. The total cost of insurances was over $\$ 1.6$ billion. The insurance 
society has possibility the insight into databases of marine incidents. In such situation, the information of too many incidents, which occurred on evaluated vessel, may be the reason of increasing the proposed insurance rate $[7,8]$.

\subsection{Importance of casualty investigations}

Notification of marine casualties and incidents which has been mandatory since $17^{\text {th }}$ of June, 2011 for all Member States of European Union to the database of European Marine Casualty Information Platform (EMCIP) operated by European Maritime Safety Agency (EMSA). The database and distribution system operated by EMSA aims to deliver many potential benefits like improving safety investigations, widening and deepening the analysis of the results of casualty investigations and giving information enabling the assessment of general risk and profiling.

EMCIP provides the means to store data and information related to marine casualties and incidents. It allows for preparing coverages of statistics and analysis of the technical, human, environmental or organizational factors involved in incidents at sea. Through preparing annually reports information about marine casualties and incidents is available to the public $[2-4,6,8]$.

Published results of investigations enable to provide for safe practices in vessel operation and a safe work environment and to establish safeguards against all identified risks or hazards allowing in the end for continuously improving safety management skills of vessel crew, including preparing for emergencies (according to section 1.2 ISM Code) [5].

\section{Final remarks}

The objectives of ISM Code are still up-to-date to ensure safety at sea, prevention of human injuries or loss of life, avoidance of damage to environment and property.

Introduced into force ISM Code cannot stop all incidents on vessels bur perhaps limit the number of them to minimum. It was the main aim of ISM Code and it may be seen the decreasing number serious incidents. There will always be incidents that could not been prevented. The Safety Management Systems (SMS) introduced on vessels (as a requirement of Code) with the best will of all crew members could not prevent all the occurrences, which may happened at sea, and ports. Of course, preparing new SMS for new vessels (especially new type) it is possible to make many fundamental faults or misjudge but through continuously changes (corrections) of SMS, it should be providing to the improvement that system.

The idea is that SMS will be compliance with a simple, logical, and wholly uncompromising concept, based on quality assurance principles. SMS shall help the crew discover bad routines and weaknesses on their vessels. The assessment of introduced into force ISM Code is positive. It was an impulse for actions providing to the improvement of safety on vessels and it was happened with the benefits to all involved parties in transport at sea and the environment.

On the other hand, ISM Code has a significant effect on insurance market. It helps for better evaluating the hazards and risks in transport at sea and through this will be able to put correct price.

It should be mentioned some incorrect phenomena which have occurred due to a necessity of confirmation (renewing an ISM Certificate every five years) that SMS works. It may be done (sometimes it is the most important matter for ship-owners) through an acknowledgment that SMS is still evaluated and lived (showing the correspondence between ship-owner and vessel, performed trainings, introduced new checklists and procedures). Sometimes the information traffic is artificial making only additional duties to the crew on management level and looks as a bureaucracy, which wastes a lot of time in a reality. Preparing daily, weekly, monthly etc. reports, trainings and exercises it is used the majority of worktime. As a result, it looks like something unnecessary. The idea of introducing ISM Code on vessels becomes distorted. It was heard such opinions from crew. 


\section{References}

[1] Dyrcz, C., Analysis of sea accidents (2002-2015), Annual of Navigation 23, pp. 151-157, 2016.

[2] EMSA, Annual Overview of Marine Casualties and Incidents 2017, EMSA report 2017.

[3] EMSA, Annual Overview of Marine Casualties and Incidents 2018, EMSA report 2018.

[4] EMSA, Safety Analysis of Data Reported in EMCIP, Analysis of Marine Casualties and Incidents Involving Fishing Vessels, EMSA report 2018.

[5] International Management Code (ISM Code), IMO, Edition (with guidelines for its implementation), London 2018.

[6] Review of Maritime Transport, United Nations Conference on Trade and Development (UNCTAD), 2018.

[7] Safety and Shipping 1912-2012, From Titanic to Costa Concordia, Allianz Global Corporate \& Specialty SE, 2012.

[8] Safety and Shipping Review, Allianz Global Corporate \& Specialty SE, 2016.

[9] SOLAS Convention (as amended), IMO, London 1974.

[10] Herdzik, J., Zdarzenia wypadkowe na morzu i ich główne przyczyny, Autobusy, Eksploatacja, Systemy Transportowe, No. 10, pp. 37-42, 2016.

[11] Herdzik, J., Analiza skutków wybranych wypadków na morzu jako zagrożeń utrudniajacych akcje ratownicze, Logistyka, No. 4, pp. 419-429, 2014.

[12] Statistical Summary Marine Occurrences 2013, Transportation Safety Board of Canada 2014.

[13] Bhattacharya, S., The impact of the ISM Code on the Management of Occupational Health and Safety in the Maritime Industry, Ph.D. Cardiff University, 2009.

[14] www.marinetraffic.com (Fig. 5. prepared on the access on $25^{\text {th }}$ March, 2019).

[15] www.energy.gov/cfo/reports (DOE Department of Energy) (accessed on $6^{\text {th }}$ April, 2019).

ORCID No: 0000-0002-2339-807X

Manuscript received 05 March 2019; approved for printing 28 June 2019 